\title{
Consumption Morality of the Locavorism Reflected in the Advertising of the Organic Fairs in Rio de Janeiro: Is the Belonging Password on the Desk?
}

\author{
Margarete Ribeiro Tavares, Fred Tavares, Bárbara Lúcia Guimarães Alves, \\ Jefferson Fernando Gonçalves Guedes da Costa, Marlen Maria Cabral Ramalho \\ Psychosociology of Communities and Social Ecology (IP/UFRJ), Rio de Janeiro, Brazil \\ Email:margatavares@yahoo.com.br
}

How to cite this paper: Tavares, M. R., Tavares, F., Alves, B. L. G., da Costa, J. F. G. G., \& Ramalho, M. M. C. (2019). Consumption Morality of the Locavorism Reflected in the Advertising of the Organic Fairs in Rio de Janeiro: Is the Belonging Password on the Desk? Advances in Applied Sociology, 9, 107-131.

https://doi.org/10.4236/aasoci.2019.94010

Received: February 15, 2019

Accepted: April 7, 2019

Published: April 10, 2019

Copyright $\odot 2019$ by author(s) and Scientific Research Publishing Inc. This work is licensed under the Creative Commons Attribution International License (CC BY 4.0).

http://creativecommons.org/licenses/by/4.0/

\begin{abstract}
The purpose of this essay is to investigate the connections that surround the morality of green consumption and locavorism from the logic of "having" to "being" under the aegis of the productilization of nature in the context of a new strand of rhizomatic capitalism that is diligently interspersed by the production of "subjectivity kits", whose theoretical bases are inspired by Gilles Deleuze and Felix Guattari. The hypothesis is related to the possibility of making desires from "subjectivity kits" based on symbolic, immaterial and intangible aspects with a moral identity proposition that promotes the relations of consumption, subjectivity, capital, "green feeding" and nature in the contemporary world. There is the possibility that a "liquefaction" of green food consumption, which is reflected by the conceptions of rhizomatic capitalism, may have been contingent upon articulations from a capilalistic culture co-opted by prêt-à-porter identities that empower themselves from the fabrication of new desires captured by social control devices. These devices can bypass their social actors, referring to the idea of Ecopower. There are indications that all this process reached the table of the Brazilian consumer in the context of locavorism from the publicity and the production of liquefied "green foods" as a brand patented by the market and aesthetized with a garment of moral consumption. In order to investigate these relationships in the field of locavore feeding, this qualitative, empirical-theoretical exploratory study was based on bibliographical-documentary research techniques based on the analysis of eight on-line advertising pieces of organic fairs in Rio de Janeiro. This study will promote an understanding of the linkages of possible intentions inserted in the advertising pieces analyzed and the expectation of a
\end{abstract}


new social control device acting in the light of rhizomatic capitalism as a manufacturer of "subjectivities kits" agitated by moral food consumption.

\section{Keywords}

Locavorism, Rhizomatic Capitalism, Morality of Consumption, Green Food, Consumption

\section{Introduction}

Contemporary capitalism has incorporated the logic of consumption based on schizophrenic and rhizomatic strategies (Deleuze \& Guattari, 1995), promoting the substitution of "being" for "having/be/seem". This capitalism may have counteracted the immateriality of consumption, associating the liquefaction of nature and its aspects through the strategies of rhizomatic capitalism (Pelbart, 2003). These strategies are based on the capitalization of what was not capitalizable from the materialization and dematerialization of the relations between nature, society and consumption, producing a kind of identity mutability that is based on mobile subjectivities (Prado, 2012) ordered by consumption.

Consumption and its regulation can occur through the production of "subjectivity kits" (Tavares \& Vargas, 2014) under the context of becoming, mutabilizing the identities of individuals and creating "new ways of being" based on "prêt-à-porter identities" (Sibilia, 2002) translated into ephemeral, disposable and fluid behaviors. These behaviors are configured as a potency of contemporary consumption enabled to manufacture socio-environmental commodification strategies. The subterfuge of these strategies praises the mutability of the behavior of the individual based on psychosocial and cultural transformations, enhancing the feelings related to the "having/be/seem" to belong.

From the perspective of Gilles Deleuze and Félix Guattari, their conceptions of the Control Society, Integrated World Capitalism and the production of subjectivities, the present study aims to promote a critical reflection on the moral purposes that serve as a basis for motivating food consumption in the context of locavism. Although it is a term still little approached by the market and by its own consumers, locavorism has become a promising segment from the pillars that support it that are social, economic and environmental. In this way, these pillars can present themselves as attributes that awaken the desire to belong to the groups that praise them, incorporating a garment that can mean a "password to belong", as if it were a disciplinary thermometer that affects the capacity of the individual to adapt to a certain behavior, allowing it to be inserted into the circle group and promote its momentary satiety.

The disciplinary devices, defended by Foucault (1987) and inherent to the Disciplinary Society, demonstrate variations of not having been extirpated by the Control Society (Deleuze, 1992). They can coexist by assuming mutant silhouettes based on control mechanisms that promote a false freedom to exercise 
subjectivity in any fad through a "password of belonging" that provides the "false illusion of belonging," as advocated by Pontes \& Tavares (2015). In this context, there are possibilities for the emergence of identities that are fabricated with ephemeral, disposable and publicizable characteristics that go beyond the conceptions of metaphysics of human nature and reach the perspectives of becoming, that is, to enjoy the virtuality of identity to invest in "becoming" through of the "human being" (Tavares \& Vargas, 2014).

This form of virtuality is promoted through the production of "kits of subjectivity" that fabricate these identities in an uninterrupted and fluid way through a kind of sinuosity of consumption that can entangle the paths covered by the Control Society. On the basis of this, Sibilia (2002) ratifies the thoughts of Rolnik (in Alliez, 2000) when she mentions that these identities have polyphonic and polycentric characteristics, according to the logic of rhizomatic capilatism (Deleuze \& Guattari, 1995), demonstrating an agency under the flow of the liquid-modern society (Tavares et al., 2017):

[...] the illusion of a fixed and stable identity, characteristic of modern and industrial society, is giving way to the "standard profile kits" or prêt-à-porter identities, according to Suely Rolnik's denominations (Sibilia, 2002: p. 33).

In the food segment, the tensions that vary between subjectivity, consumption and nature, arouse restlessness in this field of reflection, presenting the issues as sustainable as an object of investigation as a "green brand" of a commodity culture supported by criteria of subjectivity (Guattari \& Rolnik, 2000). The "green" theme makes possible a protagonism in the lenses of the new order of the World Society of Control and of marketing as a device of social control (Deleuze, 1992), through the apprehensions that surround the relations between subjectivity, capital and consumption. This new order is recognized by Hardt and Negri (2001) as an "Empire" acting through a global market and the companies that compose it, driving the desire to "be inside", although they never can feel the full satiation of belonging.

In the midst of the green market, the debate is widened from the standpoint of rhizomatic capitalism with market attributes of a Control Society that presents consumption as the primordial vector (Deleuze, 1992), incorporating organic messages and sustainability with an ecosophical garment (Guattari, 1981) from connectionist, intangible and natural characteristics (Pelbart, 2003). This prerogative in the light of the market (network) platforms (Deleuze \& Guattari, 1995) promotes the speculation of an outbreak of productilizations of nature in distinct segments, such as organic food in the context of locavism.

The locavorism is equivalent to the production and negotiation of organic foods in a radius of up to $160 \mathrm{~km}$. With this, it is possible to promote local improvements from the pillars that sustain the locavore movement, which are: Economic, enabling an increase in income for the organic producer and the development of the local economy through the generation of jobs, more income and consumption; Social, promoting the valorization of local producers and allowing direct contact with their consumers, as well as reducing food inequalities 
and the waste caused by transporting food over great distances; Environmental, enhancing the sustainable cultivation of food without pesticides and avoiding the emission of gases from the longinquity of transport between the producer and the commercial places. This movement presents characteristics that denote variations of its appropriation as a marketing strategy that promotes the rise to groups that are suppliers of social identities that take possession of a morally correct consumption.

Thompson (1993) mentions that the market economy exalts consumption from privileges that involve its profits through self-interests, while moral consumption highlights the value of fulfilling social obligations that exalt the greater good. However, veiled capitalist messages that are attributed to consumption promote the possibility of rhetoric that produces nature and causes tensions between the market and society. The factors that mediate this relationship demonstrate skills that represent the spectrum of an infinite interaction between what is morally right for the market and what is for society.

In this context, Kristofferson et al. (2014) argue that the desire to present a positive image to others may be conflicting with greed for consistency with one's values. The confrontation addressed by the authors (op.cit.). Corroborates with the logic of rhizomatic capitalism (Pelbart, 2003), since it is based on the assumption that the behavior of social actors can be regulated by the market from a capitalist culture that is organizes according to the logic of the production of nature mediated by the strategy of "natura/naturata" and "natura/naturans" (Spinoza, 2007) according to market processes. This effect demonstrates a slight breeze that renews and amplifies the notion of responsible consumption through a morality based on the transformation of branded nature to be consumed in the market by means of distinct mediatic enunciation assemblages (Deleuze \& Guattari, 1997).

Hence, the possibilities of the success of the organic fairs locavores may be interspersed by the conflicts that vary between "having" and "be/being/seem", because their consumers are attracted in different ways. Based on these possibilities, we come to the central objective of this work, which is to investigate the conflicts that involve the consumption of organic foods, the market, the subjectivities and the morality of the locavore consumer in Rio de Janeiro. Starting from the supposed scenario, the possibilities of reflection of the "green" food consumerism are investigated from the perspective of the production of "kits of subjectivity" based on the morality of consumption through the logic of rhizomatic capitalism. Based on this, it is questioned: "the password of belonging is on the table?"

The theoretical shortcuts addressed in this work follow the thoughts of the philosophers Gilles Deleuze and Felix Guattari, as well as authors who dialogue with them in an interdisciplinary way based on the investigated object. The methodology adopted is qualitative of exploratory character and it is applied from the reading and bibliographical analysis that stimulates the thematic ones on the morality of the consumption, subjectivity, capitalism and nature. The results of 
this essay will be elaborated from the documental analysis of advertising pieces of organic fairs with profile of locavorism published in online media in Rio de Janeiro. The selection of the pieces will be based on searches of the venues of these fairs and the online advertising pieces that are used to publicize them. This reading will contribute to the elucidation of the intentional aspects of the advertising pieces analyzed and the attributes of the rhetoric and the images that attract their consumers.

\section{Mechanisms of Rhizomatic Capitalism: The Materialization of Moral Consumption}

The rhizomatic capitalism (Pelbart, 2003) identifies the transformation of what was not capitalizable into capitalizable by anticipating consumer desires, exploiting assimilations with all that gives it well-being. This sensation is potentialized by approaching the values of the individual from their processes of attitude, pleasure, doing, having, and the ways of being that are uplifted by the groups to which they belong. In this logic, Rhizomatic Capitalism tends to promote a false satiation in people so that it is possible to maintain the restlessness of consumption and enhance its model of economic architecture, transforming the immaterial into material to be made available and consumed in the market.

Considering contemporary consumption, the predominance of capitalism culminates in the Liquid Modernity (Bauman, 2001) that perfects Integrated World Capitalism (GUATTARI, 1987) to be replaced by Rhizomatic Capitalism (Pelbart, 2003) through processes of adaptation to market novelties. The adaptations of the capitalist models promote feelings that act directly in the production of desires and in the feedback of this process in a continuous way. The brands have a strong participation in this production, as they become flags of symbolism that surround the identities desired by consumers.

In the light of psychosociology, the continuous and metamorphic flow of consumption produced by the brands refers to the aegis of Rhizomatic Capitalism because they appropriate the desire of individuals to produce "subjectivity kits" (Tavares \& Vargas, 2014) through the fabrication of liquid identities, flluid, and enabled to pursue earnest desires through the immanent pleasure of incomplete satiety. The authors (op.cit.) Argue that the political role of brands in the Control Society (Deleuze, 1992) is associated with the incentive of the compulsion to "having", keeping the unfinished and promoting the obsession for the best permanently.

In the tracks of Rhizomatic Capitalism (Pelbart, 2003), the order of consumption is coined and prompted by the indebtedness of individuals who feel impelled to lead a life underlined by the desire and brands that promote the "new ways of being" (Sibilia, 2002) linked to new lifestyles. This context is staged by the advertising market through the media that presents new brand models (Ferreira \& Tavares, 2017) in the light of the production of an incessant consumption. Branding models are immaterial because they model and remodel themselves to the taste of intangible desires. In the same sense, the materialization of 
desires are converted into consumption.

Baudrillard (1995) extends this discussion through the transformation of goods into "sign merchandise", which is sustained by their interpretations and values through society. In this context, there is the substitution of the initial value of the consumption of a product by the value of its exchange for another. Modernity is called by Baudrillard (op.cit.) As the "empire of the sign" in function of the transformations of goods into signs and vice versa, engendering the sterilization of reality through advertising. This, in turn, acts in the transformation of value into a reality more original than it really is and manufactures new truths that will be associated with symbolic representations. In this logic, the Consumer Society (BAUMAN, 1999) is incorporated by Integrated World Capitalism (GUATTARI, 1990) and promotes the brand's value through a postmodern context. For Tavares and Irving (2009):

"The commodity (object) is less important in the discourse of consumption and, in its place, brands appear with spirit, personality and value. Likewise, the insatiability of desire along with free consumption, which wants to be seduced, is evident (op. cit., p.50-51).

Capitalist consumption is immanent and possesses movements of belonging and displacement to assimilate the values of an image that corresponds to the "seem" or the "being inside", defended by Hardt and Negri (2001). In this process, the media that germinate "collective assemblages of enunciation" (Deleuze \& Guattari, 1995, 1997) operate through the model of Integrated World Capitalism (Guattari, 1981) as a mode of subjectivity production that articulates in a process of global production, reviving capital and unfolding in Rhizomatic Capitalism (Pelbart, 2003). In this logic, consumers want to desire boundaries and do not want full satisfaction due to the multiple feelings produced by the "subjectivity kits" (Tavares \& Vargas, 2014) that are also longed for and consumed voraciously.

The "subjectivity kits" (op.cit.) make movements of strategies of belonging to float and not plunge into consumption, constantly enabling an open feeling for the next desires. Trademarks operate to accompany these movements at the same time as they are accompanied, resulting in subjective and schizophrenic ambiguities through different axes that may or may not contradict each other. In this context, consumption is not identified as a simple ideology because it generates a vicious cycle that has no end, but is nevertheless desired.

One of the reasons for the performance of this cycle is the consumption morality that is supported by the presentation of an individual image that is at the same time collective, because it obeys veiled rules that are discreetly extolled by the Control Society (Deleuze, 1992). Moreover, contemporaneity promoted a strong approximation between ethical theories and moral actions, affecting not only human conviviality but also consumer relations. In this context, Serrano (2010) discusses the "ethics of coexistence" that demonstrates vestiges of withdrawal from "individual happiness" and approximation of "social happiness". This relationship is supported by specific actions that can be collective or not, 
but that result from a movement of moral and social conscience and that go beyond words, because they rely on possible representations through consumption.

Lakoff and Johson (1980) argue that words do not only express communication, but also articulate moralities and forms of regulation that are subjective. Through the use of words it is possible to disseminate questions of moral character that tend to regulate behaviors. There are indications that moral consumption is the result of communication relations in which certain behaviors are presented as a passport to belonging to the target groups. Publicity and marketing actions tend to constantly use the rhetoric that act as a transportation tool to disseminate certain convictions and it is at this stage that it becomes possible to produce what was not producible, materializing ideals and norms.

The determination of the moral norms will define the brand models (Ferreira \& Tavares, 2017) that will be embodied in the "subjectivity kits" (Tavares \& Vargas, 2014) available in the market and the inciters of consumption based on ethical issues. The question that involves incitement to moral consumption is related to the autonomy of the individual. How far does autonomy work in behavior related to moral consumption? The liquid and volatile subjectivities associated with consumption tend to offer consumers the "false sense of free will" because they are governed by the orchestra of producing "subjectivity kits." These, in turn, tend to generate incoherence in the senses because at one point it is consumed and in another it is rejected to be replaced by newly fabricated new subjectivities (SILVA et al, 2016).

The "false sense of free will" reflects the "exaltation of consumption as an authentic exercise of personal autonomy by certain 'ethics of capitalism"' (Cortina, 1999: p. 36). The author (op.cit.) Alludes to the ethics of capitalism in two aspects. The first argues that the individual has his desires compelled by the productive system. The second mentions that the productive system is determined by consumption. At this point, the perspectives surrounding ethics and consumption concomitantly demonstrate characteristics of being produced within the scope of the desire to belong tied to the morality that provides the illusory realization of "being" because it reached the "have." In the midst of this web that is formed between the market and the desires, emanates the conscious consumption that is backed up in respect for nature and its contemplation on the part of the individuals who "consume".

The conscious consumer came to be recognized through his ideals that defend the environment and the animals while at the same time striking the business relations with nature. Efing (2011: p. 125) addresses this behavior as "[...] the need for consumers (of goods and services) to become agents of 'critical control' of sustainable development." In this attempt, moral consumption enters relations between individuals and is appropriated by the market. Portilho (2005) calls individuals who present this profile as "green consumers". Considering the moral consumption in an environmental dimension, the "green consumer" approach becomes elucidative by reaching spaces that surpass the limits of quality 
and price variables, since it can enjoy its "power of choice" considering environmental variables and preferring products and brands that have attributes that do not harm the environment.

In this logic, "green consumption" has enhanced the ability of consumers who act in groups and replace brands that do not fit their ideals. Thus, preferences motivated by environmental considerations have gained an essential role for the market and the consumer is the main responsible, since their demands tend to promote "changes in the energy and technological matrixes of the production system" (op.cit. p. 03). Therefore, it is possible for nature to present itself in the form of a product.

Considering the mechanisms of Rhizomatic Capitalism (Pelbart, 2003), there are vestiges that the production of the non-producible reached nature and made it available in the market to be consumed through a link with moral consumption. This bond is not limited to the tangible because the convictions associated with this process demand for an understanding that goes beyond the limits of the product and reaches the behavioral patterns and the desire to be through the having. The market leaves hints that consumers have shifted their ethical actions from moral consumption to the foods they consume. Thus, organic food in the context of locavorism inherited from this market a politically correct clothing and widely sought after by individuals who are attracted by nature and by socio-environmental responsibility. For a better understanding of this logic, the next topic will contemplate this discussion in light of theories that form the basis for the present study.

\section{The Production of Nature through Organic Food in the Context of Locavorism}

The productilization of nature goes through the actions involving the association of natural sustainable parameters to the contemporary market. This, in turn, tends to exalt products and services that meet the desires of consumers concomitantly the uninterrupted production of subjectivities. In addition to this logic, there is the possibility of the development of new market niches aimed at the consumption of "green products" and brands that associate their portfolio with sustainable projects, commodifying and producing nature to the point of making it liquid (Ferreira \& Tavares, 2017).

The behavioral and marketing contradictions inherent to the processes of nature production demonstrate clues to having reached the consumer's table from a healthy eating cloth produced responsibly in a sustainable way and praised by groups that present attractive and motivational attributes of belonging. In the same proportion, these individuals may also present contradictory, fluid and schizophrenic behaviors, since they value the foods produced in the mentioned context concomitantly to the consumption of others with industrialized origin and without the guarantees praised by the organic segment. In this logic, the individual tends to present restrictions to some foods and not to others, consuming both in a paradoxical way. 
In the midst of the new demands of the market that exalt nature through their products, locavorism is feasible, which refers to the food category inherent to organic classification, equivalent to the production and consumption of food in a radius of up to $160 \mathrm{~km}$ (Azevedo \& Peled, 2015). Its relationship with "green products" (Ferreira \& Tavares, 2017) is interspersed with attributes that penetrate the pillars that sustain it (Azevedo, 2015), which are:

1) Society: Involves the support and respect for the human and work rights that work in the generation of food security. It also promotes the reduction of food waste resulting from malfunctions and consequent discards coming from the main routes. In addition, it is salutary to emphasize that direct contact with the consumer tends to value the performance of the producer. For the consumer, feelings of security and perception of food quality arise, as well as the appreciation of the producers of the food they purchase, as mentioned by Heloisa Bio at Auá Institute (Bio, 2017).

2) Economy: The local economy is largely privileged because of the income that is obtained by the producers. These, in turn, consume where they live, generating more employment and more income and increasing consumption. With this, there is the feedback of an economic cycle that contributes to the development of places that survive with few resources and did not envisage expansion horizons.

3) Environment: Locavity throws its responsible gaze on natural resources and their forms of exploitation (water, air, land, among others). In this context, the great challenge is to produce and negotiate as closely as possible so as not to lose the quality of food and maintain the purity of the growing places. With the reduction of the route between production and commercialization, it was possible to reduce the emission of toxic gases in the environment. The absence of insecticides and other pesticides also contribute to the purity of the air, since the spraying of these products compromises not only the neighboring plantations, but also the oxygen inhaled by the people.

The diversity of feelings generated by the attributes of locavorism tied to its pillars culminate in the production of "subjectivity kits" that are manufactured by markets that present the identities desired by individuals who are eager to belong. This fabrication of controversial feelings can motivate actions of nature production (Ferreira \& Tavares, 2017) as a tool of attraction for the market considered sustainable and politically correct. In this context, locavorism has reached a high level of gourmetization of natural foods that do not undergo genetic mutations, but rather subjective ones. Through this, one can observe the possibility of the occurrence of nature production through foods that enjoy the image that promotes the belonging of the individual that unfolds in the "new ways of being" (Sibilia, 2002) and in the formation of "identities prêt -a-porter" (Rolnik, 1997) supported by "having "to "being".

The productilization of nature has reached the consumer's table in order to involve it in urban garden projects and in the valorization of local production and consumption (locavorism) that can present themselves as movements of re- 
sistance, power, activism and idioms through the Control Society (Deleuze, 1992). In this context, it is necessary to understand the exploitation of "green brand models" (Ferreira \& Tavares, 2017) as one of the ways to legitimize "net sustainability" and its scope in the market. This form of sustainability is based on capitalist culture, the production of "subjectivity kits" (Tavares \& Vargas, 2014) and the "escape line" processes advocated by Deleuze and Guattari (1995).

Consumers who, even if they "unconsciously" adopt "green brands" as a way of satisfying their desires, also meet their needs for belonging and sustainable awareness through this type of consumption. In this logic, nature can be offered as a product transformed into a kind of "password" that the individual acquires to feel part of a particular group, praising everything that is related to the "green". This view contemplates locavism because it heeds the strands that are extolled by its followers, such as the three pillars that sustain it (Social, economic and environmental). Moreover, it is also possible that the "green brands" receive impulses from activist consumers defending their ideals (Hernandez, 2010). In this logic, there is still the possibility that activism has become a mark that is desired by individuals who demand acceptance and belonging to specific groups as a kind of identity that associates it with a certain form of behavior. The brands that are considered "green" may be going through this type of process.

The "green marks" have removed their limitation to simple signs and specific nomenclatures. When reaching the consumer table these brands promote the possibility of becoming "food brands" "patented" by the Organic Market. The organic classification is one of the most approached with regard to the production of subjectivities. This is because the term "organic" refers to a purity of food that is not always total, but exudes great power of seduction towards consumers. Thus, this classification promoted a food profile that has neither linearity nor chronology because it produces limited, incomplete feelings of satisfaction and produces more desires without any previous definition.

The next topic promotes the elucidation of the relations between the productilization of nature and the foods that are traversed from a market dress that potentiates the "food gourmetization". This relationship culminates in appropriations carried out by a market that extols the groups that value sustainable consumption concomitantly with the decoration of the "food brands". With this, one can identify great possibilities of the market turning nature into a product that can be available on supermarket shelves concomitantly the incomplete satisfaction of those who consume it. This is because when the individual feels satiated, new subjectivities will arise that will culminate in desires.

\section{The Nature Consumed as "Food Label"}

The immateriality of the "green brands" has developed into "green products" that have reached the production of consumer desires and can be recognized as fads or activism. In the case of Organic Food, branded models (Ferreira \& Tavares, 2017) present themselves as "food brands", which individuals consume, even if they pay more, and show that they are supporters of groups that absorb 
everything belonging to them. "Green marks".

The "green food brands" follow the market flows defended by Pelbart (2003), where everything is negotiable. Healthy foods have created a kind of "food label" that is consumed by those who wish to belong to groups that advocate sustainable actions and adopt specific ways to legitimize their ideals. In the context of the consumption of nature, its process of transformation into product demonstrates symbolic characteristics of appropriation by the market in a way that makes it attractive from seductive mediatic rhetoric with social and environmental appeals grounded in a communication that supports sustainable logics that provoke consumer concerns (Carvalho, 1996).

In this context, Berger and Luckmann (2004) mention that the symbolic universes order desires of belonging through a social dynamic that legitimizes behaviors of empowerment and reaffirmation of the individuals through the society. These universes coexist in parallel references for a projection of the future. Holliday (2002) corroborates the aforementioned considerations based on marketing and communication efforts. This is based on images that are created for this market from the logic of a show (Pelbart, 2003).

Complementing Pelbart's (op.cit) thoughts, Debord (1997: p. 25) argues that "[...] the spectacle is capital in such a degree of accumulation that it becomes an image." From this, environmental marketing starts to act as a mediator between social control devices and advertising as a strategy driven by rhizomatic/intangible capitalism that result in "soul brands" (Tavares, 2003; Kotler, 2010). From this, the tangible (product) becomes the symbolic (brand modeling) that reflects the "I" without the need for rhetoric that already have their meanings for the market, that is, the "I belong" gains a refinement of who without the need to be influenced. However, the analysis of advertising pieces can demonstrate that they act in a way that interferes with the consumption choices available in the market.

Such approaches are discussed through the association between movements and eating practices. Family farming, organic agriculture, locavism, urban permaculture, slow food, vegetarianism, veganism and flextarianism have gained ground in the supermarket market, supermarket media and shelves. Azevedo and Peled (2015) cite that under these conceptual aegis are the inherent attributes of food consumption in the activist context that involves terms such as ethics, locality, tradition, insurance, animal friend, among others. For Pelbart (2003), nothing is free from commerce and everything can be commodified. Thus, every form of food activism becomes an art in the eyes of the market and this is transferred to the consumer through publicity actions and events that attract the attention of consumers and result in a kind of "food art", this term, adopted by Azevedo and Peled (2015).

"Food artistry" (op.cit.) Is one of the aspects of food gourmeting processes, transforming it into "brands" that are desired for consumption due to its sustainable clothing. This occurs when the organic foods resulting from the process of locavism receive sophisticated attributes from the perspective of the market 
and society as a strategy to produce nature (Ferreira \& Tavares, 2017). In this context, it can be observed that the relationship between the "subjectivity kits" (Tavares \& Vargas, 2014) and the "food labels" presents plural characteristics, since both can arouse feelings that surround the bonds that are produced by the mercantilization of nature through food.

Thus, the perspective of a market and social scenario of the subject's suitability to vice-versa persists, promoting a rhizomatic choreography without defined steps and the generation of new ramifications without bases of absolute or transcendent values. The aforementioned scenario is supported by pillars mixed by feelings and values that fabricate "kits of subjectivity" (op.cit.) And produce fluid and schizophrenic desires. This scenario can be sponsored by a kind of "password of recognition" that allows the identification that allows a "false illusion of belonging" (Bridges \& Tavares, 2015) in order to allow a temporary satiation, but that allows a feeling of social and consumer empowerment.

Based on the present study, there are indications that sustainable consumption has developed a "password of belonging" that allows the recognition of individuals and their ideals from their consumption preferences. To elucidate this connection, the next topic will present some clues of the said possibility of correlation.

\section{Is the Belonging Password on the Table?}

By capitalizing on what was not capitalizable through Rhizomatic Capitalism, Pelbart (2003) refers to a possible promotion of individuals' insatiability as a strategy for enhancing their model of economic architecture. This archetype transforms the immaterial into material to be consumed and promote feelings that result in "subjectivity kits" (Tavares \& Vargas, 2014) that open space for a "false illusion of belonging" (Pontes \& Tavares, 2015). This feeling is considered misleading because it is momentary, since the individual already initiates a new process of making desires, feeding back a cycle that is vicious and has no goal to finalize its existence.

In this context, the marks become a passport of belonging through its consumption. The Consumer Society in the light of Liquid Modernity (Bauman, 2001) refers to sustainable issues as a marketing possibility for the maintenance of "new ways of being" (Sibilia, 2002). With this, there is a rupture of the predictable consumer links, making them schizophrenic and subjugated by nature concomitantly with the goals of Rhizomatic Capitalism (Pelbart, 2003).

In the context of the conceptions of decentralized, global and rhizomatic capitalism (Guattari, 1981, 1991; Deleuze \& Guattari, 1995), consumption is identified as a subterfuge of social regulation of control that enhances and motivates the ideals that "Being" is necessary "having" and "seem", because when this does not happen, a subliminal process of exclusion takes place.

The Deulezean context argues that the Control Society (Deleuze, 1992) turns consumption into a "password of belonging". This permission to belong unifies 
and diffuses the personal and the collective, imploding the connections between "being outside" and "being inside" (Hardt \& Negri, 2001). With this, the individual tends to always feel "outside" and aims to "have/seem" to "be in", which feeds the cycle of making wishes uninterrupted. This cycle turns the individual into an eternal indebtedness, since he can not remove the consumer mortgage from brands and "new ways of being" (Sibilia, 2002) that are produced and reconfigured by the logic of the world market. This representation culminates in liquid, flexible, ephemeral, and schizophrenic identities that undergo a sort of "patent" of a captivating and appealing market for consumers eager to "have/seem" permanently as an irreplaceable member of a becoming process.

In this context, the "belonging password" refers to a kind of passport so that the individual feels integrated into the desired group. The "password" can be related to their mode of consumption which, in the case of this study, refers to food locavores, allowing consumers to identify the possibility of belonging based on products that can express their personality through society. When considering that the consumer can feel ownership based on "green foods" that are offered in their family environment should also be considered that the "belonging password" may be on the "table."

Tavares et al. (2000) argue that the "new way of being" (Sibilia, 2002) "green" assures the relevance of the individual in the Consumer Society (Bauman, 2001) representing the "human being" in the processes of "being/seem" eager for socio-environmental and sustainable innovations. The "green" portfolio is attractive, multicolored and with attributes that mix ethics and aesthetics as a protective film of the "password of belonging" that is acquired from consumption. This portfolio is acquired, consumed and discarded, since its slopes are constantly deconstructed without a deepening that allows the formation of loyalty and fidelity.

This relationship of constant approximation and decoupling can be identified in the consumer's table through the number of food categories linked to organic classification, which are: Locavorism, vegetarianism, strict vegetarianism, veganism, flextarianism, protovegetarianism, semi vegetarians, pescetarianism, crudivorismo, egglactovegeratian, egg-vegetarianism, lacto-vegetarianism, frugivorism, freeganism, and macrobianism (Freegan.Info, 2018; Cantinhovegetariano.com, 2018; Centrovegetariano.com, 2015; Keys, 2012, Zanin, 2018, Estilovegan.com, 2018, Oliveira, 2017, Eusemfronteiras, 2018; Sociedadevegana.org, 2010; Jaminealimentos.com, 2017; Chaves, 2012). The identification of these categories grounded the increase in the demand for "green brands", since they may have become a "password of belonging" to the moral consumption that surrounds the consumer's desk.

In order to solidify the understanding of the processes underlying the manufacturing of green market-related desires associated with consumer feeding that enhance sustainable marketing attributes with distinct fundamentals, this essay will present in the topic below the basis of the development of its research. 


\section{Research Development}

The present study is inspired by the concepts of control society, rhizomatic capitalism and the production of subjectivities from the perspective of Gilles Deleuze and Félix Guattari. From this, it becomes possible to reflect the psychosocial and cultural transformations that human beings are exposed through the consumption approach. The possible interpellations do not contemplate the metaphysical conceptions of human nature, since they emphasize the perspectives of "becoming", mutabilizing the social identities of individuals through market strategies.

Following this route of thought and dilating the analysis about a market scenario subsidized by the Control Society (Deleuze, 1992), whose driver is consumption, there are possibilities of revealing nature as an object of investigation transvestite "culture of merchandise" (Guattari \& Rolnik, 2000). This possibility can be analyzed from the perspectives that cover the goals of Rizomatic Capitalism (Pelbart, 2003) and from marketing actions as a device of social control (Deleuze, 1992). Thus, nature presents clues to incorporating new values with distinct perspectives on the relationships between society and the "green" ecosophy (Guattari, 1991).

In this logic, this research approaches the aspects that appropriate the theme of sustainability as a strategy of empowerment both for social actors and the holders of "green brands", making new demands and building new brands with elastic, fluid and disconnected aspects, whose socio-environmental/ecological rhetoric is its indelible mark (Tavares et al., 2015).

From the provocations and the reading provided, the demand for reflections and investigations that contemplate the relations between consumption, capital, subjectivity and nature is reached, enhancing the development of the "green food market" in Brazil, specifically in Rio de Janeiro, that is a city recognized for its natural attributes, which becomes an incentive to "green" consumption. From this approach it is possible to carry out an investigation that surrounds the paths covered by the consumption of "green food" with a garment that refers to morality from locavorism as a vector that sustains the production of subjectivities based on rhizomatic capitalism inserted in the context of control society.

For the development of this study, initially the exploratory bibliographic search was selected with the objective of forming a theoretical framework that supports the necessary investigations. It is a qualitative exploratory research based on the bibliographical readings that surround the themes of consumption, capital and subjectivity. The analysis will take place in eight virtual advertising pieces of locavores organic fairs in Rio de Janeiro. The pieces were randomly selected in order to exclude interferences in the analysis of the communication objectives implicit in the images.

The analyses will take place based on two possibilities that are the characteristics of productilization of the nature or referring to the locavores pillars that are: Social, Economic and Environmental. With this, it will be possible to associate 
the forms of communication of these advertising pieces with the behavior of the consumer locavore, since marketing is the tool used to attract people to the consumption, being able to reach its audience in a positive or negative way. The morality of consumption associated with "green brands" is one of the aspects of the contemporary market and demand for research that promotes its elucidation. For this, the analyses that will be debated in the next topic will occur.

\section{The Organic Fairs Locavores in Rio de Janeiro: An Analysis of Seductive Media Tracks}

In order to contemplate the concepts discussed in this essay, eight virtual advertising pieces were selected from organic fairs locavores held in Rio de Janeiro and broadcast nationally. The objective is to investigate a scenario of possible "production of nature" (Ferreira \& Tavares, 2017) reaching the consumer table in a seductive way and arousing the desire to belong to the groups that exalt the "green products" in a cut made in Rio de January.

Going along a trail that promotes the consumption of organic food locavores and aims to reach the "charm" of attending an organic fair in the mall, Figure 1 demonstrates evidence of a changing environment of the individual. Based on the productilization of nature, the advertising piece of the Shopping Fashion Mall marks a logic that sublimates the individual as a representative of the consumer object based on sustainable ideals. Through this, there is the conversion of healthy food into aesthetic and possible "password of belonging" to groups that extol healthy identities, producing "subjectivity kits" (Tavares \& Vargas, 2014) that are seduced by a sophisticated and attractive image.

The publicity piece of Uptown's Organic Fair epitomizes the image of nature's production through an event that camouflages the fair amid diverse attractions such as live music and the gourmetization of organic food. The Sound of the Market is an event that can be inserted in the context of "food label" because it presents with an elegant program of ecologically correct appearance, but without the conception of the main objectives of the organic fairs locavores, that are the economy, the environment and society. Thus, Figure 2 does not reach the rogative to which organic events submit, leaving clear clues that nature can become a product sought by a market that demands products with dressmaking characteristics that seduce its consumers through possibility of partially satisfying their desires and immediately producing other.

Figure 3 contrasts the previous ones according to the image that transports the consumer to the reach of the locavore's pillars. The pillar of the economy is assimilated through negotiations that will generate income for producers and boost the economic aspects of their places of origin. The social pillar plays a key role in the contact of farmers directly with their consumers, enabling the feeling of relevance and respect for both parties. The environmental pillar is identified under the aegis of healthy looking foods from a sustainable production process. However, these messages are subliminal and the other activities that will occur in the event receive all the emphasis that could be directed to the main objectives of 


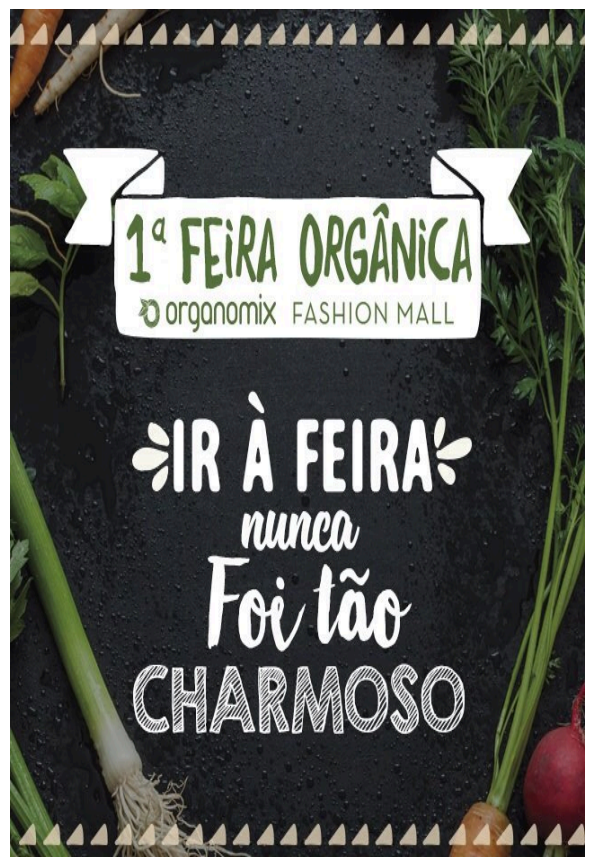

Figure 1. Shopping fashion mall organic fair: Organicsnet.com (2015).

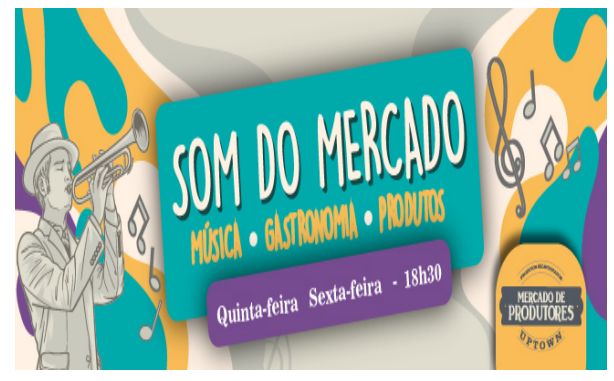

Figure 2. Uptown organic fair (Barra da Tijuca): Uptownbarra.com (2017).

organic fairs locavores. Thus, Figure 3 shows a distortion of the intentions that surround sustainable attributes and for environmental purposes.

Figure 4 shows characteristics that detract from the sustainable and responsible objectives of advertising related to organic fairs locavores. This is because the logo of the organic fair is presented as just a detail among sponsors and other activities that will occur. The "Farmer's Party" is in fact a fair that does not have in its objectives a "commemoration" for the event but rather the practice of locavorism and the fulfillment of the demands of its consumers through the producers' offer, leading to the loss of environmental intentions and natural resources. The play neither enhances the trade show nor its objectives, characterizing it as a "sustainable flag" camouflaged in the midst of several other attractions that may have a power of seduction and potential agency, producing empty sustainable identities that can be replaced more easily at any time. 


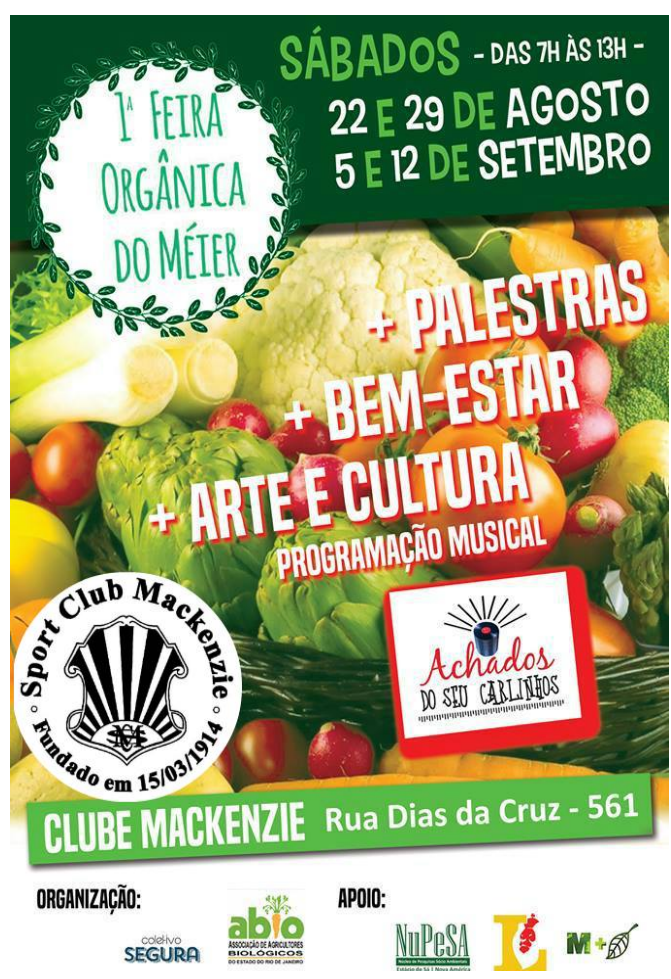

Figure 3. 1st Meier organic fair: Soumeier.com (2018).

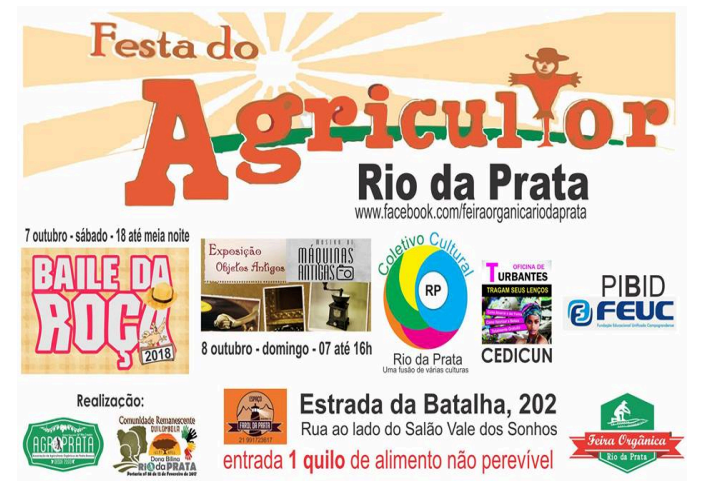

Figure 4. Organic Fair of the River Plate:

Facebook.com/Feiraorganicariodaprata (2018).

Figure 5 demonstrates an advertising piece of the Urca Organic Fair that inserts it in the role of coadjuvant the protagonist who is the Design Projects Fair of the PUC-Rio students. Even if the main focus of the piece is the design projects, the fair is the veteran of the place and has no relation with the course that presents the exhibition. In this logic, one can observe the migration of socio-environmental responsibility for attracting visitors to the fair, that is, a transfer of values occurs in the face of the partnership of the two events. This is because there is no relation between the objectives of the two actions, it makes it impossible to associate one idea with another (Pelbart, 2003), it is possible to identify that the pillars that sustain the locavorism in the organic fairs have received a clothing that leads them to insert in a universe of production of 


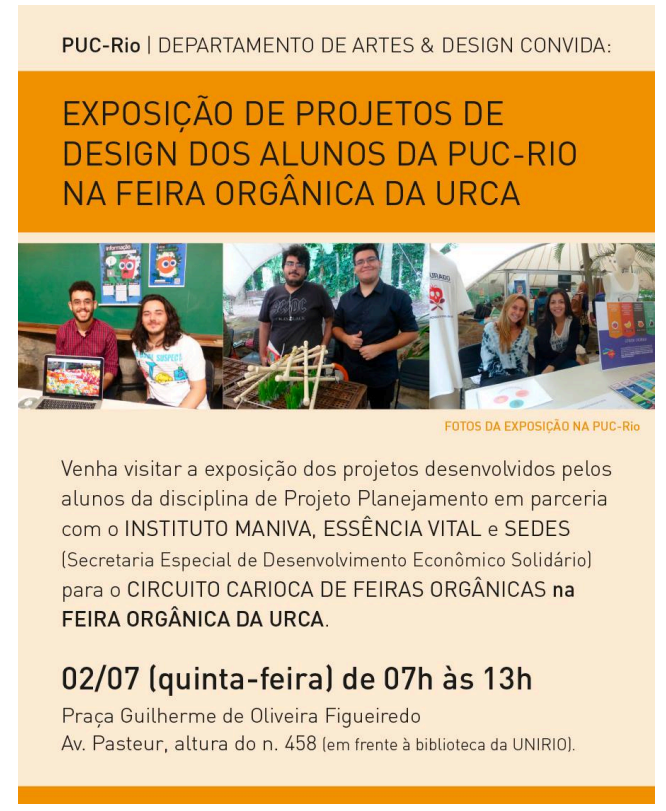

Figure 5. Urca Organic Fair: Allevent.in/rio (2018).

"subjectivity kits" that manipulate the advertising (Pontes \& Tavares, 2015) in the context of the Control Society (Deleuze, 1992).

Figure 6 demonstrates the gourmetization of organic food with a "food label", because it presents the image of the sophistication associated with "green consumption", spectacularising the concept of sustainability with references to "consumption morality". It may be the indication of one of the "new ways of being" (Sibilia, 2002) appropriated by a contradictory market in its environmental and consumer aspects that demonstrates its insertion in the current global themes with an ecological simulacrum discourse inspired by the semiotization of the "nature production" as a strategy of valuing the sustainable approach, sensitizing the consumer and stimulating their market attributes.

Figure 7 and Figure 8 contradict Figure 1 because both occur inside a mall, but with different objectives in relation to the locavores pillars. The images present the foods as prominent and healthy looking. The Organic Yard and Organic Fair nomenclatures advance towards the sentiment of a family crop, motivating the consumers of organic food locavore. The incentive coming from the publicity pieces does not demonstrate nature's productiveness, although the fairs take place inside shopping malls, these being, environments that do not match this type of market. From this perspective, it is possible to identify an ambiguity of intentions, since the fairs offer agricultural products in sophisticated environments and distinct from their origins.

From the analyzes made on the discussions promoted in this essay, the final considerations will be presented in the next topic.

\section{Final Considerations}

The morality of "green" food consumption runs through winding clues that deal 


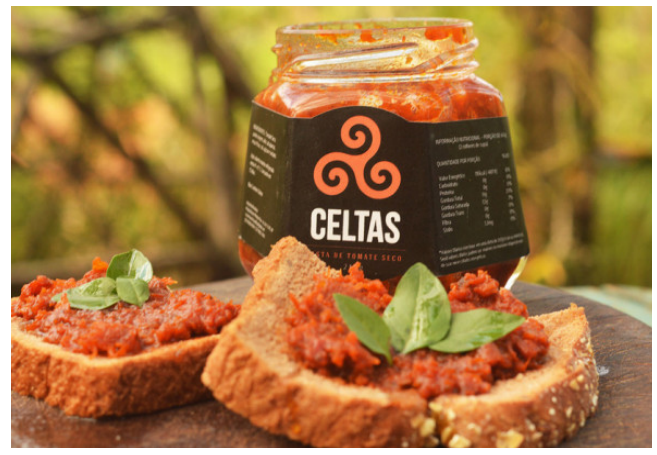

Figure 6. Organic fair of the plaza shopping niterói: Promoview.com (2019).

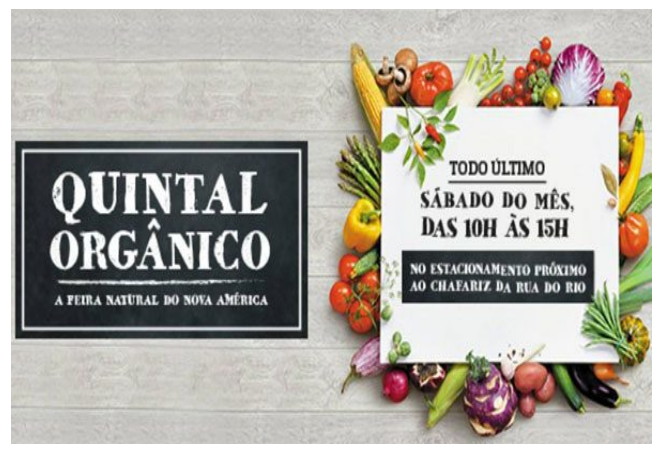

Figure 7. Organic fair of shopping nova américa: Soumeier.odia.com (2019).

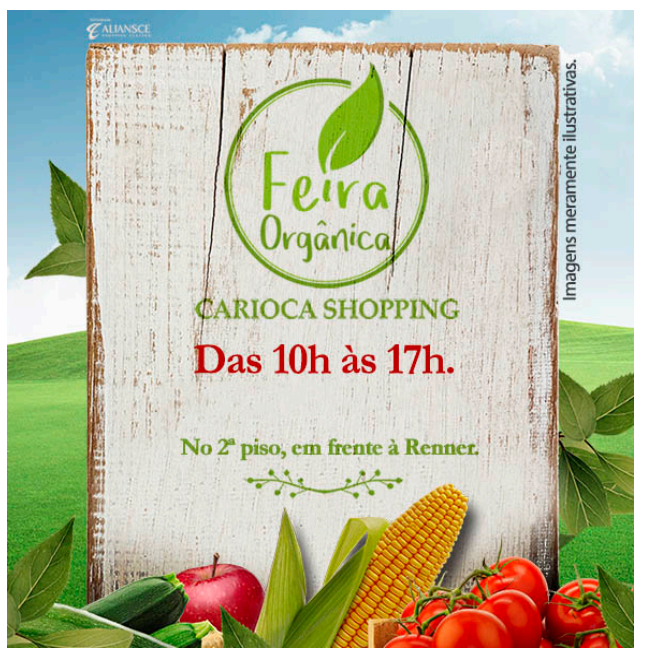

Figure 8. Carioca Shopping Fair: Cariocashopping.com (2019).

with the processes of transforming fixed identities into rhizomatic, flexible, immaterial, and ambivalent behaviors, reflecting subjectivity as the backdrop for the production of desires that are partially satiated in unfinished models. This relentless satiation is supported by the incessant fabrication of the "desire to desire." Through this, there is the multiplicity of feelings resulting from the "sub- 
jectivities kits" that surround the "green" market actions, demonstrating clues that they have reached the table of consumers in order to extol "new ways of being" based on the "new modes of feeding "that are molded into seductive shapes that function as" passwords of belonging".

In this context, individuals enter the environment of the market metamorphoses that reflect self-deformed models to form again through a deconstruction supported by "kits of subjectivity" that encourage consumption. This relationship can be portrayed by the agency of corporate capital associated with the media that becomes the owner of invisible green patents with sustainable and environmental attributes in a responsible and exemplary way. These patents demonstrate possibilities of being appropriated by the food market with healthy and moral aspects.

The morality of consumption may present attributes that are not always related to ethics, but rather the attainment of a "prêt-a-porter identity" equivalent to politically correct, empowered and dressmakers actions. Consumption greed sharpens innovations with amplifying contours that demonstrate a long spectrum in order to "produce nature" in a food context that pulsates by market-driven variations. Amid uncountable possibilities, ranks and food categories emerge that provide a variety of "prêt-a-porter identities " that can be purchased as if they were available on supermarket shelves.

These conceptions are altered by the production of "subjectivity kits" in which their responsible logic relates to the constitution of "food labels" patented by the exaltation of food gourmetization that are extracted from nature without any refinement or sophistication. However, they receive a garment that inserts them into fanciful and "liquid" imaginaries that are appropriated by social actors with completely different behaviors, but who are recognized by consumerist characteristics that attract them to compose groups or repel them to stand out through society. In this logic, the severe relationship between capital and consumption is net and metamorphic in the context of the Control Society.

The commodification of individual life has reached the collectivity in the form of consumption of everything that can be subtly transformed into an object of desire, plasticizing nature and offering it in the market from "green patents" that appropriate environmental attributes both in the idealistic context as well as fadism. In this sense, nature becomes productive and receives the identification of a commodity-sign that is incessantly oxygenated by the efforts of environmental marketing and "green advertising", both with attractive and sustainable characteristics through a society that values the natural and makes wishes based on this logic.

The publicity of "green speeches" through media actions aimed at food can be observed in the marketing actions of organic fairs. These movements can be identified in images supported by the roots of Rhizomatic Capitalism from the capitalization of what was not capitalizable and made available in a market full of subjectivities attached to identities that allow the acquisition of the passwords 
that promote individuals to the desired belonging. The approach of the sustainable discourse of productilization of nature to food of locavore origin can be developed not only by the companies, but also by the media, as identified, in an exploratory way in pieces of online publicity of organic fairs in Rio de Janeiro.

The comparison between the images illustrates a process of ambiguity of goals and feelings that seduce the consumers through publicity pieces that reach their audiences through actions that vary according to the production of "subjectivity kits" that attract individuals who become protagonists of a scene that legitimizes devices of empowerment through society. These processes are interspersed by influences, controls, productions and mutual consumption based on attractive and tensional market plateaus. The qualitative analyzes of the images were based on the direct and indirect messages composed in each advertising piece. This essay has identified capitalistic practices in the midst of marketing actions that may be the result of an implicit demand exalted by consumers who wish not only to consume but "having" to "being".

The capitalistic practices associated with marketing actions culminate in a new social order that promotes nature to the level of brand/label associated with discourses composed by ethical makeup that are removed by the new mask that will assume its position with similar rhetoric and constantly related to the logic of the "politically correct". Rio de Janeiro is a city that contemplates nature due to its scenic aspects, referring to a healthy population that values sustainable and responsible practices. By means of this, the city was selected as a clipping for the analyzes that composed this essay.

Thus, the moral consumption of "green products" acts in the condition of the capitalist culture that is elucidated through landscapes, geographic/social identities, brands, services, empty discourses, utopian products and healthy individuals that spectacularize the quality of life based on the singularization of green modes of being/feeding. "The link between nature, food, subjectivities, capitalism and consumption are dictated by the connections established by net consumer behaviors that capture, create and denigrate to recreate different values with innovative conceptions of an imperialist kaleidoscope composed of subtle facets capable of execution of this process as a vicious circle.

Moreover, the morality of the consumption of "green foods" presents itself as a driving force for the productivization of nature inserted in the context of rhizomatic capitalism from the production of "subjectivity kits" that awaken multifaceted identities composed by the desire to desire. Predefined healthy identities associated with the residents of Rio de Janeiro demonstrate clues to strong Control Society influences through schizophrenic, fluid and liquid contradictions in order to share desires and unsustainable attached to the "having/seem" to be.

\section{Conclusion}

From the research that culminated in the analysis of the advertising pieces of organic fairs in Rio de Janeiro, it was possible to identify that of the eight pieces 
analyzed, only one presented characteristics that lead the consumer to reach the locavores pillars, which are: Social, economic and environmental. The other pieces present attributes of attraction for consumption, however, without the necessary elucidations about the origin of the foods and the benefits they offer. This attraction with an empty stamp refers to a process of production of nature. However, it should be noted that consumers are attracted to what interests them, which is, there is a great possibility of the locavore audience feeling motivated from the desire to belong.

When the "green consumer" is attracted to publicity campaigns that demonstrate distinct goals of the locavores, the possibility arises that he demands for a belonging from a moral behavior exalted by society. In this case, the individual can carry out his purchases in an organic fair and consume industrialized products concomitantly, that is, only to feel belonging.

Organic fairs with characteristics of locavorism attract consumers with different objectives; however, the analysis of advertising has provided the assimilation that most advertising pieces are aimed at consumers who demand fashion. It is worth noting that it is not an exclusivity, because locavorism is a food category extolled by consumers who demand for healthy products and based on the locavores pillars. However, the provocative question of this research has been answered subtly through images that are used to attract consumers.

Based on this, it can be mentioned that the "belonging password is on the table" because the consumer starts to feel inserted in a determined group from the "green food" that is present in their meals. This food and its presence at the fair become a kind of passport to exercise an identity through society and feel "inside", even momentarily, since new subjectivities are produced in an uninterrupted way, making it feel "outside" again and motivating new forms of consumption, this behavior, consistent with the control society.

\section{Conflicts of Interest}

The authors declare no conflicts of interest regarding the publication of this paper.

\section{References}

Allevent.In/Rio. https://allevents.in/rio\%20de\%20janeiro/exposi\%C3\%A7\%C3\%A3o-dos-projetos-dosalunos-de-design-da-puc-rio-na-feira-org\%C3\%A2nica-da-urca/773503639437622\#

Azevedo, E. (2015). O Ativismo Alimentar na perspectiva do Locavorismo. Ambiente \& Sociedade, 18, 1-18.

Azevedo, E., \& Peled, Y. (2015). Artevismo alimentar. Contemporânea-Revista de sociologia da UFSCAR, 5, 495-520.

Bauman, Z. (2001). Modernidade líquida. Rio de Janeiro: J. Zahar.

Berger, P. L., \& Luckmann, T. (2004). A construção social da realidade: Tratado de sociologia do conhecimento. Rio de Janeiro: Editora Vozes.

Bio, H. (2017). Paulistas terão livro inédito sobre agricultores da maior feira orgânica da 
capital, no parque da Água Branca. Instituto Auá de empreendimento socioambiental. http://institutoaua.org.br/paulistas-terao-livro-inedito-sobre-agricultores-da-maior-fei ra-organica-da-capital-no-parque-da-agua-branca/

Cantinhovegetariano.com. Alimentação sem carne do Dr. Eric Slywitch. http://www.cantinhovegetariano.com.br/2007/06/tipos-de-vegetariano_03.html

Cariocashopping.com. Feira Orgânica Carioca Shopping. https://www.facebook.com/feirasorganicas/photos/a.1435880726436748/143588075643 $6745 /$ ?type $=3 \&$ theater

Carvalho, N. (1996). Publicidade, a linguagem da sedução. São Paulo: Ática.

Centrovegetariano.com (2015). https://www.centrovegetariano.org/Article-70-Tipos\%2Bde\%2Bvegetarianos.html

Chaves, F. (2012). Tipos de vegetarianos: Entenda as principais diferenças entre os grupos de vegetarianos.

https://www.vista-se.com.br/tipos-de-vegetarianos-entenda-as-principais-diferencas-e $\underline{\text { ntre-os-grupos-de-vegetarianos/ }}$

Cortina, A. (1999). Ética del Consumo: Por un consumo justo y de calidad. Claves de Razón Práctica, No. 97, 36-42.

Debord, G. (1997). A sociedade do espetáculo: Comentários sobre a sociedade do espetáculo. Rio de Janeiro: Contraponto.

Deleuze, G. (1992). Conversações. Rio de Janeiro: Ed 34.

Deleuze, G., \& Guattari, F. (1995). Mil platôs: Capitalismo e esquizofrenia (Vol. 1). Rio de Janeiro: Ed. 34.

Deleuze, G., \& Guattari, F. (1997). Mil platôs: Capitalismo e esquizofrenia (Vol. 4). Rio de Janeiro: Ed. 34.

Efing, A. C. (2011). Fundamentos do Direito das Relaçóes de Consumo (3a edição). Curitiba: Juruá Editora.

Estilovegan.com. O que é crudivorismo. https://estilovegan.com.br/o-que-e-crudivorismo

Eusemfronteiras.com. Os diferentes tipos de vegetarianismo. https://www.eusemfronteiras.com.br/os-diferentes-tipos-de-vegetarianismo

Facebook.com/Feiraorganicariodaprata. Feira orgânica Rio da Prata. https://www.facebook.com/feiraorganicariodaprata/photos/p.1129445510519935/11294 $\underline{45510519935 / \text { type }=1 \& \text { theater }}$

Ferreira, G. G. T., \& Tavares, F. (2017). Natureza líquida: As modelagens marcárias e os modos de ser na publicidade verde. Rio de Janeiro: Appris Editora.

Foucault, M. (1987). Vigiar e punir: Nascimento da prisão. Trad. Lígia M. Ponde Vassalo. Petrópolis: Vozes.

Freegan.info. O que é freeganismo. https://freegan.info/what-is-a-freegan/translations/o-que-e-freeganismo

Guattari, F. (1981). Revolução molecular: Pulsões políticas do desejo. São Paulo: Brasiliense.

Guattari, F. (1991). As 3 ecologias. Campinas: Papirus.

Guattari, F., \& Rolnik, S. (2000). Micropolitica: Cartografias do desejo. Rio de Janeiro: Vozes.

Hardt, M. A., \& Negri, A. (2001). Império. Rio de Janeiro: Record.

Hernandez, A. (2010). Imagens e discursos do movimento social espanhol "No a la guerra": Representações, ações e reações. In G. Pedrinho, A. Hernandez, \& M. Cárdenas 
(Eds.), Representaçóes sociais em movimento: Psicologia do ativismo político. Porto Alegre: EDIPUCRS.

Holliday, C. et al. (2002). Cumprindo o prometido: Casos de sucesso do desenvolvimento sustentável. Rio de Janeiro: Campus.

Jaminealimentos.com (2017). Tipos de vegetarianos: Do vegano ao crudívoro: Entenda as diferenças.

https://www.jasminealimentos.com/alimentacao/9211-tipos-de-vegetarianos/

Kotler, P. (2010). Marketing 3.0: As forças que estão definindo o novo marketing centrado no ser humano. Rio de Janeiro: Elsevier.

Kristofferson, K., White, K., \& Peloza, J. (2014). The nature os Slacktivism: How the social observability of na initial act of token support affects subsequente prosocial action. Journal of Consumer Research, 40, 1149-1166. https://doi.org/10.1086/674137

Lakoff, G., \& Johnson, M. (1980). Metaphors We Live By. Chicago: University of Chicago Press.

Oliveira, S. (2017). O que é um pescetariano e o que comem? http://www.nutricaointegrativa.com/o-que-e-um-pescetariano-e-o-que-o-comem

Organicsnet.com (2015). 1'a Feira Orgânica Organomix e o Shopping Fashion Mall no sábado no RJ.

http://www.organicsnet.com.br/2015/07/1a-feira-organica-organomix-e-fashion-mall-a contece-nesse-final-de-semana-no-rj

Pelbart, P. P. (2003). Vida capital: Ensaios de biopolítica. São Paulo: Iluminuras.

Pontes, F., \& Tavares, F. (2015). Kits de subjetividade e antropofagia: Algumas considerações sobre o consumo e a publicidade na sociedade de controle. Trabalho apresentado no DT-06 do Intercom Nordeste 2015.

http://www.portalintercom.org.br/anais/nordeste2015/resumos/R47-1542-1.pdf

Portilho, F. (2005). Consumo sustentável: Limites e possibilidades de ambientalização e politização das práticas de consumo. Cadernos EBAPE.BR., 3, 1-12.

http://www.scielo.br/pdf/cebape/v3n3/v3n3a05

Prado, L. S. (2012). Em busca da identidade perdida. Revista Panorama, 2, 81-87. http://revistas.ucg.br/índex.php/panorama/article/view/2140/1319

Promoview.com. Feira Orgânica do Plaza Shopping Niterói. https://www.promoview.com.br/shopping/feira-de-organicos-no-plaza-shopping-niter oi.html

Rolnik, S. (1997). Toxicômanos de identidade. Subjetividade em tempo de globalização. Reelaboração de artigo publicado no caderno "Mais!" da Folha de São Paulo. http://www.pucsp.br/nucleodesubjetividade/Textos/SUELY/Toxicoidentid.pdf

Serrano, P. J. (2010). Ética Aplicada: Moralidade nas relações empresariais e de consumo. Campinas: Alínea.

Sibilia, P. (2002). O homem pós-orgânico: Corpo, subjetividade e tecnologias digitais. Rio de Janeiro: Relume Dumará.

Sociedadevegana.org (2010). Protovegetarianismo. http://sociedadevegana.org/textos-fundamentais/protovegetarianismo

Soumeier.com. Feira do Méier. https://www.soumeier.com.br/todas-as-noticias/eventos/primeira-feira-organica-do-m $\underline{\text { eier }}$

Soumeier.odia.com. Feira Orgânica do Shopping Nova América. https://soumeier.odia.com.br/todas-as-noticias/eventos/nova-america-promove-feira-o $\underline{\text { rganica-todo-ultimo-sabado-mes }}$ 
Spinoza, B. É. (2007). Belo Horizonte: Autêntica Editora.

Tavares, F. (2003). Gestão da marca: Estratégia e marketing. Rio de Janeiro: E-Papers.

Tavares, F., \& Vargas, R. (2014). O "ter humano" e os "kits de subjetividade": Uma perspectiva psicossociológica do consumo através da publicidade. Revista Conexóes PSI, 2, 109-127.

Tavares, F., Silva, A. A., Ferreira, G. G. T., Tavares, M. R., \& Miranda, R. M. (2017). The "Green Consumption" and the Rhizomatic Capital Strategy: Ads and Reports in the Brazilian Media. Open Journal Scientific Research Publishing, 7, 35-63.

Tavares, F., Torres, G., Pontes, F., \& Töpke, D. R. (2015). Women Go Shopping. Discussing the Female Intergenerational Behaviour and the Green Consumption. Open Journal of Social Sciences, 3, 172-181.

Thompson, E. P. (1993). Customs in Common: Studies in Traditional Popular Culture. New York: New Press.

Uptownbarra.com (2017). Som do mercado. http://uptownbarra.com.br/evento

Zanin, T. (2019). Ovolactovegetarianismo: O que é e seus benefícios. https://www.tuasaude.com/ovolactovegetarianismo 